\title{
Management Considerations to Enhance Use of Stock Ponds by Waterfowl Broods
}

\author{
MARK A. RUMBLE AND LESTER D. FLAKE
}

\section{Abstract}

Use of 36 livestock watering ponds by mallard (Anas playtrhynchos), blue-winged teal (A. discors), and total broods was tested against 32 habitat variables from 1977 and 1978. Pond size, shallow water areas with submersed vegetation, number of natural wetlands in a 1.6-km radius, and emersed regetation composed of smartweed (Polygonum spp.) and spikerush (Eleocharis spp.) were associated with increased use of ponds by total broods. When analyzed by species, small grain on the surrounding section and height and density of shoreline vegetation were associated with increased use of ponds by mallard broods; percent of shoreline with trees and percent arrowhead (Sagittaria spp.)/water plantain (Alisma spp.) were associated with decreased use of ponds by mallard broods. Percent river bulrush (Scirpus fluviatilis)/burreed (Sparganium spp.) was associated with decreased use of ponds by blue-winged teal.

Approximately 220,000 livestock watering ponds (stock ponds) have been constructed on the northern high plains (Bue et al. 1964), of which 88,000 are in South Dakota (Ruwaldt et. al 1979). These ponds were constructed to improve livestock utilization of forage on rangelands, but they have also received considerable use by waterfowl (Bue et al. 1952, 1964; Smith 1953; Ruwaldt et al. 1979). Many public land managers and private land owners have indicated interest in management strategies designed to increase the value of these ponds for alternate uses while maintaining use by livestock. This study was conducted to further identify habitat variables important to the use of stock ponds by waterfowl broods.

\section{Study Area}

The study was conducted in Jones and Lyman counties in south

Rumble is research wildlife biologist, Rocky Mountain Forest and Range Experiment Station, Rapid City, S. Dak., in cooperation with South Dakota School of Mines and Technology. The Station's headquarters is in Fort Collins, in cooperation with Colorado State University. Flake is professor, Department of Wildlife and Fisheries Sciences, South Dakota State University, Brookings.

The South Dakota Agricultural Experiment Station (Project H-615) and the South Dakota Water Resources Institute (Project A-038-SDAK and B-045-SDAK) contributed to this study. W. L. Tucker, statistician, South Dakota Agricultural Experiment Station, provided recommendations on sampling procedures and statistical analyses. Gene Mack, Michael Rabenburg, and Steve Tessman provided field assistance. central South Dakota. The study area was $1,235 \mathrm{~km}^{2}$, bordered by the towns of Murdo to the west and Vivian to the east. Native vegetation was typical of mixed grass prairie (Johnson and Nichols 1970:8). Principal land uses of this area were pasture (71-80\%) and wild hay (3-6\%), with crops (milo, sorghum, wheat, sunflowers) making up the remainder (Johnson and Nichols 1970).

\section{Methods}

Thirty-six stock ponds were selected for study based on 2 criteria: (1) they were at least $2.5 \mathrm{~km}$ from the nearest other study pond; and (2) they were between 0.6 and $3.0 \mathrm{ha}$ in size. The selection criteria was designed to reduce the chance of broods moving from one study pond to another as a result of census efforts and to reduce, if possible, the influence of pond size on use of the pond by waterfowl broods. All ponds were larger than the minimum size recommended by Lokemoen (1973) for waterfowl.

Waterfowl broods were counted in July and August 1977 and 1978. Two census techniques were used to increase accuracy of brood use data (Hammond 1970). Broods were first counted by hidden observers with a $25 \mathrm{X}$ spotting scope during the 2.5 hours prior to sunset and following sunrise. Flush counts were conducted by different personnel after the morning observations (Rumble and Flake 1983). Species, brood size, and age-class (Gollop and Marshall 1954) were used to identify broods and eliminate duplication in combining data from the 2 surveys.

Thirty-two variables considered to be important to use of ponds by waterfowl broods were collected for each pond. Specific conductivity, $\mathrm{pH}$, and the disappearance depth of a secchi disc (Beeton 1958) were recorded. Percent of pond with emersed vegetation and percent composition of emersed vegetation on each pond were estimated. Categories of emersed vegetation were as follows: cattail (Typha spp.); round-stemmed bulrushes (Scirpus acutus and $S$. validus); river bulrush (S. fluviatilis)/ burreed (Sparganium spp.); arrowhead (Sagittaria spp.)/water plantain (Alisma spp.); spikerush (Eleocharis spp.); and smartweed (Polygonum spp.). Percent of the basin filled with water, percent bare shoreline, and mean height of emersed vegetation were estimated visually. Basin size and surface water area were determined by planimeter from aerial 
Table 1. Means and range in data for habitat variables which were significantly $(\alpha \leq 0.05)$ different between 1977 and 1978.

\begin{tabular}{|c|c|c|c|c|}
\hline \multirow[b]{2}{*}{ Variable } & \multicolumn{2}{|c|}{1977} & \multirow{2}{*}{$\frac{1978}{\bar{x}}$} & 1978 \\
\hline & $\bar{x}$ & range & & range \\
\hline $\begin{array}{l}\text { pH } \\
\text { Index of submersed vegetation in } 0 \text { - to } 61 \text { - depth } \\
\text { zone } \\
\text { Percent smartweed } \\
\text { VOR's of shoreline vegetation } \\
\text { Hectares of corn, milo, or sorghum }\end{array}$ & $\begin{array}{c}8.52 \\
161 \\
9.3 \\
1.27 \\
28.8\end{array}$ & $\begin{array}{c}7.1-9.3 \\
18-300 \\
1.0-39.0 \\
0.03-4.07 \\
6.8-71.9\end{array}$ & $\begin{array}{c}8.83 \\
240 \\
35.1 \\
2.38 \\
16.0\end{array}$ & $\begin{array}{r}7.7-9.9 \\
12-492 \\
1.0-99.0 \\
0.14-6.35 \\
2.1-36.9\end{array}$ \\
\hline
\end{tabular}

photographs (1:4132). Shoreline development was determined according to Lind (1974). Distance to the nearest road, distance to the nearest stock pond, the number of stock ponds within a $1.6-\mathrm{km}$ radius, and the number of natural pond basins within a $1.6-\mathrm{km}$ radius were obtained from the aerial photographs. Land use categories of small grain (wheat); corn, milo or sorghum; pasture; idle; and hay on the adjacent section of upland were mapped on aerial photographs and acreages determined with a planimeter. Estimates of submersed vegetation in the 0 - to $61-\mathrm{cm}$ depth zone were made by multiplying frequency of occurrence in $40,60-\mathrm{X} 60-\mathrm{cm}$ quadrats spaced equidistance around the pond, by the mean vegetation coverage rating (Rumble 1979). Percent of the pond 0 - to $61-\mathrm{cm}$ deep, percent of the pond $0-$ to $61-\mathrm{cm}$ deep with emersed vegetation, and percent of the shoreline with trees along it were estimated. Shoreline vegetation data were obtained by the visual obstruction reading (VOR) method (Robel et al. 1970) from 12, 20-m transects, spaced equidistance around the pond and at right angles to the shoreline. Presence of livestock in adjacent pastures or fields was recorded.

Analyis of variance was used to show which habitat variables were different between 1977 and 1978. All possible combinations (32!) of the variables were evaluated in multiple regression equations. The combination of variables with the highest $R^{2}$ was interpreted for analyses and discussion herein. July data were used for the analyses because of the larger number of waterfowl broods present. Separate regression analyses of data from the 2 years would provide insight into the habitat variables waterfowl broods responded to during 2 different years. However, long-term habitat management plans for waterfowl usually cannot be drastically changed from year to year. Therefore, data from both years were used for regression analyses. Multiple regression equations were developed for total broods, mallard (Anas platyrhynchos) broods, and blue-winged teal ( $A$. discors) broods. In addition to mallard and blue-winged teal broods, total broods included pintail ( $A$. acuta), gadwall (A. strepera), northern shoveler
(A. clypeata), and American wigeon (A. americana) broods. All variables and relationships discussed were significant at $\alpha \leq 0.05$.

\section{Results and Discussion}

\section{Brood Utilization}

Blue-winged teal were the most common waterfowl broods utilizing study ponds, composing 44 and $37 \%$ of the total number of broods in 1977 and 1978, respectively. Mallard broods were the next most common in both years, accounting for 27 and $24 \%$ of the total number of broods, respectively. Therefore, management of stock ponds to include habitat characteristics for these 2 species would benefit the majority of waterfowl being produced on stock ponds in this area of the northern high plains.

\section{Year Differences}

In terms of habitat and duck production, 1977 and 1978 were quite different. The spring of 1977 was dry following drought conditions in 1976, and ponds did not fill until May or June. The rest of 1977 and the following year had average or above-average precipitation; ponds were full and many fields had standing water during the 1978 spring migrations of waterfowl. Yellow sweetclover, in its second season of growth on range areas, was in suitable condition to provide good nesting cover during May and June. By July sweetclover in pasture areas was commonly over $1 \mathrm{~m}$ high. The VOR measurements of shoreline vegetation around study ponds during 1978 were significantly higher (Table 1) than during the previous year $(2.38 \pm 0.31$ vs. $1.28 \pm 0.17)(\bar{x} \pm S E)$. In 1978 significantly ( $\alpha \leq 0.001)$ more broods (232) were seen on study ponds than in $1977(85)$. Submersed vegetation in the 0-61 cm depth zone and percent smartweed significantly increased in 1978 $(\alpha \leq 0.05)$. Submersed vegetation increased following drawdown from previous drought conditions and subsequent reflooding. Smartweed also were expanding into areas that were dry 2 years previous. The amount of land planted to corn decreased significantly in 1978 and there were increases in land planted to wheat and alfalfa in 1978. However, statistically, the latter 2 were not signifi-

Table 2. Habitat variables associated with waterfowl brood use of stock ponds as indicated by stepwise forward multiple regression.

\begin{tabular}{|c|c|c|c|}
\hline Species and habitat variables" & $\begin{array}{l}\text { Standardized partial } \\
\text { regression coefficient }^{b}\end{array}$ & $\begin{array}{l}\text { Coefficient of } \\
\text { determination } R^{2}\end{array}$ & $\begin{array}{l}\text { Simple correlation } \\
\text { coefficient }(r)\end{array}$ \\
\hline \multicolumn{4}{|l|}{ Blue-winged teal broods } \\
\hline Pond size & +0.42 & 0.19 & 0.43 \\
\hline Number of natural pond basins within a $1.6-\mathrm{km}$ radius & +0.29 & 0.28 & 0.28 \\
\hline Percent river bulrush/burreed & -0.25 & 0.34 & -0.32 \\
\hline \multicolumn{4}{|l|}{ Mallard broods } \\
\hline Submersed vegetation in $0-$ to $61-\mathrm{cm}$ depth zone & +0.29 & 0.16 & 0.40 \\
\hline Pond size & +0.28 & 0.28 & 0.28 \\
\hline Hectares of small grain (wheat) & +0.34 & 0.36 & 0.22 \\
\hline Percent of shoreline with trees & -0.38 & 0.40 & -0.26 \\
\hline VOR's of shoreline vegetation & +0.26 & 0.46 & 0.28 \\
\hline Percent arrowhead/water plantain & -0.21 & 0.50 & -0.25 \\
\hline \multicolumn{4}{|l|}{ Total broods ${ }^{\mathrm{C}}$} \\
\hline Pond size & +0.34 & 0.15 & 0.39 \\
\hline Submersed vegetation in $0-$ to $61-\mathrm{cm}$ depth zone & +0.24 & 0.23 & 0.21 \\
\hline Number of natural pond basins within a $1.6-\mathrm{km}$ radius & +0.24 & 0.29 & 0.20 \\
\hline Percent smartweed & +0.31 & 0.34 & 0.33 \\
\hline Percent spikerush & +0.27 & 0.40 & 0.24 \\
\hline
\end{tabular}

Variables are listed in the order they were entered into the equation.

Sign of the standardized partial regression coefficient indicates the association of variable in this set of variables, absolute value indicates the relative importance.

All species of waterfowl seen during this study: 
cant increases.

\section{Regression Analyses}

Of the 32 habitat variables considered, only 10 were significantly associated with mallard brood, blue-winged teal brood, or total brood use of study ponds (Table 2). Pond size was entered into all equations despite the selection of ponds within a narrow size range $(0.6$ to $3.0 \mathrm{ha})$. In all cases pond size had a positive simple correlation ( $r$ ) with numbers of broods. Size of ponds or impoundments was found to be important to waterfowl brood production in studies by Smith (1953), Berg (1956), and Lokemoen (1973). Lokemoen (1973) recommended the minimum pond size be at least 1.5 acres ( $0.6 \mathrm{ha})$ and that the maximum size be dictated by topography and economics. Pond size was also correlated to shoreline length, which was important in determining brood use in studies by Mack and Flake (1980). Some other habitat variables showed significant changes between years similar to those observed for numbers of broods; however, broods were most closely associated with pond size.

The number of natural pond basins within a $1.6-\mathrm{km}$ radius of a study pond was positively associated to both blue-winged teal broods and total broods. The study ponds had between 3 and 17 natural pond basins within this proximity. These pond basins generally contain water only during spring and early summer months anad are important to the breeding physiology of nesting waterfowl hens (Krapu 1974, Krapu and Swanson 1975). They also tend to attract breeding pairs (Schroeder et al. 1976), which should result in more broods. Lokemoen (1973) recommended construction of stock ponds near other wetlands. Broods utilizing shallow basins will move to more permanent sources of water when these water sources dry as summer progresses (Evans et al. 1952:43; Mack and Flake 1980).

Submersed vegetation in the 0 - to $61-\mathrm{cm}$ depth zones of ponds was associated with mallard broods and total broods. Submersed vegetation provides habitat for aquatic organisms (Krull 1970) which, in turn, are an important food item for waterfowl broods (Swanson and Sargeant 1972, Swanson and Meyer 1973, Sugden 1973). The majority of submersed vegetation on study ponds was composed of Potomogeton spp. and Myriophyllum spp. Submersed and floating leaved hydrophytes were the most important factors affecting use of flood control structures by waterfowl in Texas (Hobaugh 1977:59).

Visual obstruction readings (VOR's) of shoreline vegetation were positively associated with use of study ponds by mallard broods. Shoreline vegetation provides loafing and escape cover for broods. Greater numbers of broods used ponds with brushy or grassy shorelines (Bue et al. 1952, Lokemoen 1973) or residual vegetation (Gjersing 1975) as opposed to bare shorelines.

Percent of emersed vegetation composed of spikerush and smartweed were positively associated with blue-winged teal broods and total broods. These types of emersed vegetation also provide secure cover for waterfowl broods for hiding or loafing. Lokemoem (1973) reported optimum brood cover appeared to be flooded brush or emersed vegetation. Both spikerush and smartweed comprised between 1 and $99 \%$ of the emersed vegetation on various study ponds. Ponds which had more spikerush and smartweed also had more broods.

Arrowhead/water plantain and river bulrush/burreed were negatively associated with blue-winged teal broods and mallard broods, respectively. Biologically, there is probably no negative effect of arrowhead/water plantain or river bulrush/burreed. However, ponds which had these types of emersed vegetation in abundance had little brood use as indicated by negative simple correlations.

The occurrence of trees along the pond edge was associated with reduced use of ponds by broods in this study. Ponds with many trees around the shoreline had fewer waterfowl broods. Trees on the Northern Great Plains have many positive values, and this relationship warrants further research.
Hectares of small grain in the surrounding section of land were positively associated with the occurrence of mallard broods on study ponds. Two successions of wheat farming were included in this variable-fields with a current crop growing and fields in which the stubble was left from the previous fall. The nesting cover provided by dense stands of wheat stubble $10-15 \mathrm{~cm}$ in height may have attracted mallard hens. Further, flooded stubble may have provided waste grain and invertebrates for feeding adult pairs. Duck production in areas of tilled lands was more successful if fall stubble was not plowed until mid July and if there was standing water in fields through the nesting season (Higgins 1977). Both conditions existed in this study to some degree. Small grain fields occupied an average of $8 \%$ (not more than $41 \%$ ) of the upland section of land surrounding study ponds. Large scale conversion of uplands to small grain would likely lead to a reduction in overall brood production on associated stock ponds (Higgins 1977).

\section{Management Suggestions}

Although these ponds were developed to increase utilization of forage resources by livestock, prudent managers and ranch operators could obtain increased hunting, aesthetic, and in some cases, positive economic values (through hunting fees) by including habitat characteristics in pond construction and management that will enhance waterfowl production. The following features of pond construction are recommended: (1) build larger ponds where possible; (2) maximize the amount of shallow water area and shallow inlets for the production of submersed and emersed vegetation; (3) distribute livestock and maintain grazing levels to allow continued growth and existence of shoreline and emersed vegetation; (4) leave grain stubble in fields until after the peak nesting period to provide nesting cover; and (5) do not drain natural pond basins in adjacent areas.

\section{Literature Cited}

Beeton, A.M. 1958. Relationship between Secchi disc readings and light penetration in Lake Huron. Trans. Amer. Fish. Soc. 87:73-79.

Bers, P.F. 1956. A study of waterfowl broods in eastern Montana with special reference to movements and the relationships of reservoir fencing to production. J. Wildl. Manage. 20:253-262.

Bue, I.B., L.H. Blankenship, and W.H. Marshall. 1952. The relationship of grazing practices to waterfowl breeding populations and production on stock ponds in western South Dakota. Trans. N. Amer. Wildl. Conf. 17:396-414.

Bue, I.B., H.G. Uhlig, and J.D. Smith. 1964. Stock ponds and dugouts. P. 391-398. In: J.P. Linduska, ed. Waterfowl Tomorrow. U.S. Gov. Print. Off., Washington, D.C.

Evans, C.D., A.S. Hawkins, and W.H. Marshall. 1952. Movements of waterfowl broods in Manitoba. U.S. Fish and Wildl. Serv. Spec. Sci. Rep. Wildl. 16.

Gjersing, F.M. 1975. Waterfowl production in relation to rest-rotation grazing. J. Range Manage. 28:37-42.

Gollop, J.B., and W.H. Marshall. 1954. A guide for aging duck broods in the field. Mississippi Flyway Counc. Tech. Sect. Rep.

Hammond, M.C. 1970. Waterfowl brood survey manual. U.S. Fish Wildl. Serv. Bur. Sport Fish. Wildl.

Higgins, K.F. 1977. Duck nesting in intensively farmed areas of North Dakota. J. Wildl. Manage. 41:232-242.

Hobaugh, W.C. 1977. Waterfowl utilization characteristics of floodwater retarding structures in north-central Texas. M.S. Thesis. Texas A\&M Univ., College Station.

Johnson, J.R., and J.T. Nichols. 1970. Plants of South Dakota grasslands. South Dakota State Univ. Agr. Exp. Sta. Bull. 566.

Krapu, G.L. 1974. Foods of breeding pintails in North Dakota. J. Wildl. Manage. 38:408-417.

Krapu, G.L., and G.A. Swanson. 1975. Some nutritional aspects of reproduction in prairie nesting pintails. J, Wildl. Manage. 39:156-162.

Krull, J.N. 1970. Aquatic plant macroinvertebrate associations and waterfowl. J. Wildl. Manage. 34:707-718.

Lind, O.T. 1974. Handbook of common methods in limnology. C.V. Mosby Co., St. Louis. MO.

Lokemoen, J.T. 1973. Waterfowl production on stock-watering ponds in the northern plains. J. Range Manage. 26:179-184.

Mack, G.D., and L.D. Flake. 1980. Habitat relationships of waterfowl broods on South Dakota stock ponds. J. Wildl. Manage. 44:695-700. 
Robel, R.J., J.N. Briggs, A.D. Dayton, and L.C. Hulbert. 1970. Relationships between visual obstruction measurements and weight of grassland vegetation. J. Range Manage. 23:295-297.

Rumble, M.A. 1979. Habitat preferences and censusing of waterfowl broods in south central South Dakota. M.S. Thesis. South Dakota State Univ., Brookings.

Rumble, M.A., and L.D. Flake. 1982. A comparison of two waterfowl brood survey techniques. J. Wildl. Manage. 46:1048-1053.

Ruwaldt, J.J., Jr., L.D. Flake, and J.M. Gates. 1979. Waterfowl pair use of natural and man-made wetlands in South Dakota. J. Wildl. Manage. 43:375-383.
Schroeder, L.D., D.R. Anderson, R.S. Pospahala, G.G.W. Robinson, and F.A. Glover. 1976. Effects of early water application on waterfowl production. I. WildI. Manage 40:227-232.

Smith, R.H. 1953. A study of waterfowl production on artificial reservoirs in eastern Montana. J. Wildl. Manage. 17:276-291.

Sugden, L.G. 1973. Feeding ecology of pintail, gadwall, American Widgeon and Lesser scaup ducklings in southern Alberta. Can. Wildl. Serv. Rep. Ser. 24.

Swanson, G.A., and A.B. Sargeant. 1972. Observation of nighttime feeding behavior of ducks. J. Wildl. Manage. 36:959-961.

Swanson, G.A., and M.I. Meyer. 1973. The role of invertebrates in the feeding ecology of Anatinae during the breeding season. P. 143-165. In: Waterfowl Habitat Symposium, Moncton, New Brunswick, Canada, July 30-August 1, 1973. 